\title{
Article \\ An Experimental Study on the Effect of Temperature on the Shear Strength Behavior of a Silty Clay Soil
}

\author{
Henok Hailemariam * and Frank Wuttke
}

Geomechanics and Geotechnics Group, Institute of Geoscience, Kiel University, Ludewig-Meyn-Straße 10, 24118 Kiel, Germany; frank.wuttke@ifg.uni-kiel.de

* Correspondence: henok.hailemariam@ifg.uni-kiel.de check for updates

Citation: Hailemariam, H.; Wuttke, F. An Experimental Study on the Effect of Temperature on the Shear Strength Behavior of a Silty Clay Soil.

Geotechnics 2022, 2, 250-261.

https://doi.org/10.3390/

geotechnics2010011

Academic Editor: Samuel Abbey

Received: 19 January 2022

Accepted: 1 March 2022

Published: 3 March 2022

Publisher's Note: MDPI stays neutral with regard to jurisdictional claims in published maps and institutional affiliations.

Copyright: (C) 2022 by the authors. Licensee MDPI, Basel, Switzerland. This article is an open access article distributed under the terms and conditions of the Creative Commons Attribution (CC BY) license (https:// creativecommons.org/licenses/by/ $4.0 /)$.

\begin{abstract}
In this paper, we report on the results of an experimental study of the yielding and shear strength behavior of a normally consolidated silty clay soil from eastern Germany. The shear strength tests were performed on remolded forms of the soil using a triaxial cell which can regulate the temperature of the specimen. The experimental program comprised a series of pressure stepping compression consolidated drained (CD) triaxial tests at temperatures of 20,40 and $60{ }^{\circ} \mathrm{C}$. Overall, although the volume change behavior of the soil was found to exhibit some variations with changes in temperature, possibly due to changes in the double layer thickness of the clay fraction of the soil upon heating, the shear strength behavior (in terms of effective angle of internal friction) of the silty clay soil was found to exhibit minor changes with variations in temperature and can be assumed to be independent of temperature for the range considered in this study.
\end{abstract}

Keywords: silty clay soil; triaxial test; shear strength; effective angle of internal friction

\section{Introduction}

Analyzing the effect of temperature changes on the thermomechanical, yielding and shear strength behavior of soils is essential for various engineering applications including seasonal thermal energy storage, freezing/thawing soil processes, hydrocarbon extraction from oil sands, radioactive waste disposal, etc. In most of these applications, the soil may experience changes in temperature of up to $30^{\circ} \mathrm{C}$ [1]. Moreover, high degrees of variations in soil temperature are commonly exhibited due to seasonal temperature fluctuations, especially in the upper soil layers of naturally occurring soils.

One of the earliest studies on the effect of temperature changes on the soil consolidation behavior was published by Gray [2]. In recent times, several modeling and experimental studies were conducted on the thermomechanical and yielding behavior of fine-grained soils at different temperature conditions [1,3-6]. Experimental investigations on the thermomechanical properties of an unsaturated silt at the temperature range of 25 to $60{ }^{\circ} \mathrm{C}$ were conducted by Uchaipichat and Khalili [7] using a modified triaxial device.

Vega and McCartney [8] performed temperature-regulated thermal consolidation tests on compacted, saturated silt specimens under normally consolidated to heavily overconsolidated initial stress states using an oedometer set-up with backpressure control. The findings of their experimental investigations showed that during initial heating, the silt specimens exhibited thermal volume changes which are similar to those reported in the literature, with the normally consolidated soils showing thermal contraction, and whereas the heavily overconsolidated soils showing thermal dilation or expansion. Additionally, in all cases, the specimens showed elastic contraction during cooling, as expected.

Moritz [9] presented the results from a laboratory study of the properties of clay at high temperatures on samples from a site close to a heat storage system. The results indicated a reduction in shear strength of the normal Swedish clay with an increase in medium temperature, with the modulus decreasing in the order of $0.5 \% /{ }^{\circ} \mathrm{C}$. 
Burghignoli et al. [1] presented the results of a laboratory study of the thermal properties of clayey soils and of the effect of temperature on their mechanical behavior. They performed the experiments on reconstituted and natural clayey soils in the temperature range between $20^{\circ} \mathrm{C}$ and $60^{\circ} \mathrm{C}$ using modified triaxial cells capable of controlling the sample temperature. Their findings showed that the response of the soil to thermal loading in drained and undrained conditions is not unique but among other factors, the recent and overall stress history directly impacts its thermomechanical behavior and in particular the soil volume changes. These soil deformations observed after heating are mainly due to the rearrangement of particles in the soil skeleton. Furthermore, they found out that the deformability and strength of the soil were relatively independent of temperature for the temperature range considered in their study.

Abuel-Naga et al. [10] studied the thermo-mechanical behavior of natural soft Bangkok clay, with temperature up to $90^{\circ} \mathrm{C}$ using a modified oedometer apparatus. Based on the findings of the experimental study, they concluded that the thermally induced volume change is dependent on the soil stress level and history, and highlighted that factors such as physico-chemical changes, soil plasticity and percentage of fines play an important role in the intensity of the thermally induced changes and in general the thermo-mechanical behavior of saturated fine-grained soils subjected to temperature changes less than the pore-liquid boiling point.

Hueckel et al. [6] attempted to explain the dependence of failure criteria on temperature for saturated clays. They pointed out that especially for the temperature range between 4 and $120^{\circ} \mathrm{C}$, the dependence of strength on temperature is material specific, and that the evolution of both the yield locus and failure is largely dependent on the thermomechanical loading history. They also reported some novel correlations between the various aspects of the thermomechanical behavior of clays, and highlighted the need for extensive experimental and modelling studies to provide a sufficient and clear assessment of the response of geotechnical systems subjected to high temperatures.

Mitchell [11] reviewed the effect of heat and temperature on the engineering behavior of soils. For saturated soils, the volume and pore-water pressure variations that are induced due to temperature changes were related to interactions of the thermal expansion of soil minerals and water, their compressibility, and changes in interparticle forces. Furthermore, a comprehensive review of thermomechanical and yielding properties of soils in view of temperature changes was carried out by Laloui [12]. In the majority of the studies, a significant dependence of the mechanical behavior of the studied soils on medium temperature was reported.

On a more practical impact of the effects of temperature change on soils, Scaringi and Loche [13] carried out a detailed review of the temperature-dependent fully coupled thermohydro-mechanical behavior of soils, and their implications on the soil slope stability and landslide analysis under climate change. They hypothesize that temperature fluctuations produced in the soil due to climate change coupled with other known factors (such as altered precipitation patterns and changes in land use) may alter important soil properties such as shear strength and compressibility, permeability and water retention capacity, thus affecting landslide activity and the frequency of occurrence and distribution of soil slope failures.

The study presented in this research aims to contribute to the existing body of work done by previous researchers studying the effect of temperature on the mechanical properties of soils, and is mainly concerned with the experimental analysis of the temperaturedependent yielding and shear strength behavior of silty clay soils. The consolidated drained (CD) multi-stage compression triaxial tests were conducted on the silty clay soil at the temperatures of 20,40 and $60^{\circ} \mathrm{C}$, using a triaxial device which can regulate the temperature of the specimen. 


\section{Experimental Plan}

\subsection{Soil Tested}

A naturally occurring normally consolidated silty clay soil with moderate density from Thuringia, eastern Germany was used in a reconstituted form for the laboratory study. In Table 1, a list of the physical and geotechnical properties of the silty clay soil is presented [14]. The results of the X-ray diffraction (XRD) mineralogical investigation of the silty clay soil are presented in Figure 1. From the results of the XRD plot shown in Figure 1, it can be seen that only the dominant minerals with a considerable comparative grain volume or mass fraction of the total soil are indicated. Thus, other mineral forms with a negligible or low comparative grain volume or mass fraction existing in the soil grain structure have not been marked in the plot.

Table 1. Physical and geotechnical properties of the studied silty clay soil.

\begin{tabular}{cc}
\hline Properties & Value \\
\hline Gravel, $>2 \mathrm{~mm}(\mathrm{wt} . \%)$ & 16.1 \\
Sand, $0.063-2 \mathrm{~mm}(\mathrm{wt} . \%)$ & 8.8 \\
Silt, $0.002-0.063 \mathrm{~mm}(\mathrm{wt} . \%)$ & 58.2 \\
Clay, $<0.002 \mathrm{~mm}(\mathrm{wt} . \%)$ & 16.8 \\
Porosity $(-)$ & 0.443 \\
Solids specific gravity $(-)$ & 2.673 \\
Bulk dry density $\left(\mathrm{g} \mathrm{cm}^{-3}\right)$ & 1.489 \\
Natural gravimetric water content (\%) & 16.8 \\
Liquid limit $(\%)$ & 34.6 \\
Plasticity index (\%) & 14.81 \\
Unified soil classification system (USCS) & $\mathrm{CL} 1$ \\
\hline
\end{tabular}

${ }^{1}$ CL: clay of low plasticity.

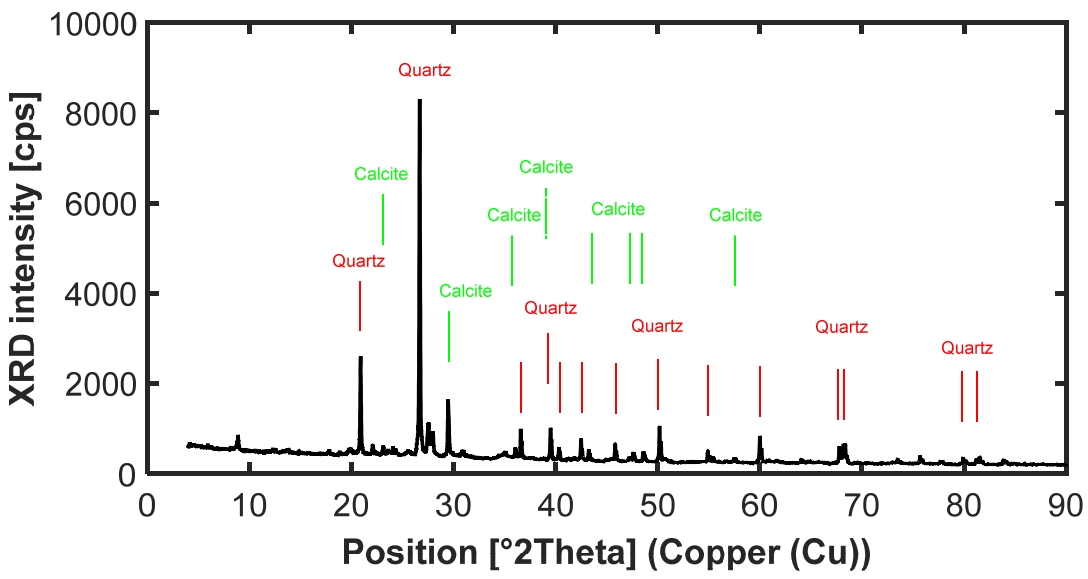

Figure 1. X-ray diffraction (XRD) plots of the silty clay soil.

\subsection{Devices Used}

A modified triaxial testing system which can control the temperature of the sample in the cell was used for performing the experimental study of the temperature-dependent shear strength behavior of the silty clay soil (Figures 2 and 3). The test set-up included: an enclosed temperature controlled triaxial cell (Figure 3), a UL-60 loading device fitted with a highly accurate load cell (type KAS-E/D) (Figure 2b), which can apply deviatoric loads of up to $60 \mathrm{kN}$, a linear transducer (TRS-0050), which has an electrical range of $50 \mathrm{~mm}$ and a $2 \mu \mathrm{m}$ repeatability, for recording displacements of the specimen in the axial direction, a double piston VPC-D 250/20 volume/pressure controller, with a capacity (volumetric) of $250 \mathrm{~mL}$ of each piston and maximum pressure capacity of $2000 \mathrm{kPa}$, used for applying and controlling the pore-water (backpressure) and cell pressure of the specimen, a pore-water or pore-gas pressure sensor (type PR-25Y), with a maximum pressure capacity of $1000 \mathrm{kPa}$, 
for recording the pore-water pressure of the sample, a heat pump (Huber Ministat 125 Pilot ONE) for regulating the temperature of the sample and the triaxial cell water using a circulating fluid, and a data logger and PC control unit for the recording of data recording and for controlling the system (Figure 2a).

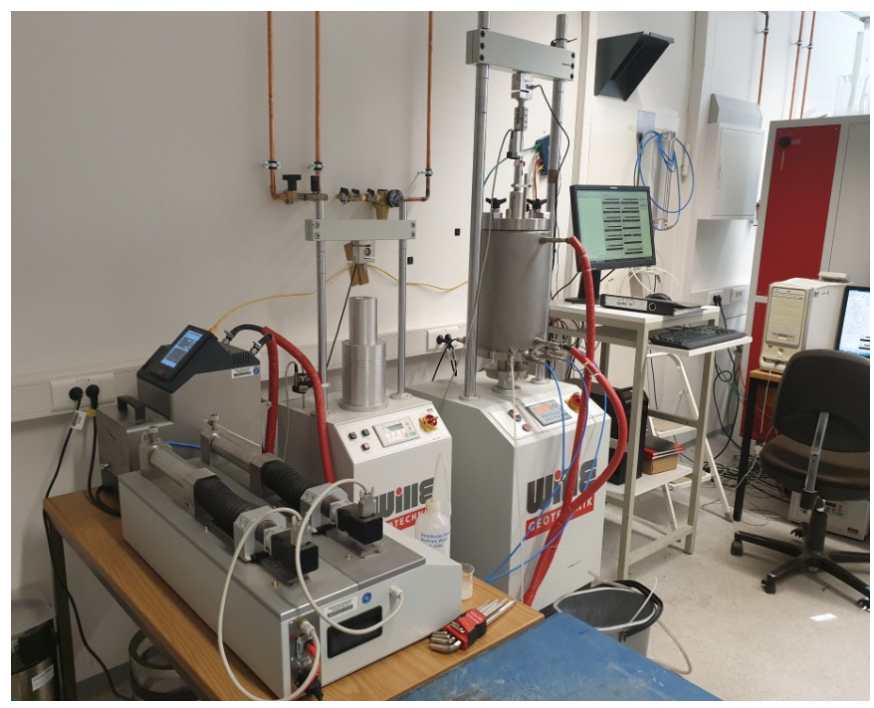

(a)

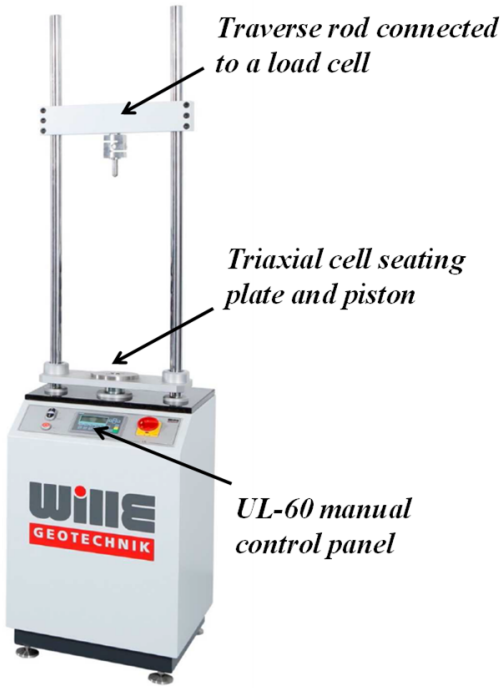

(b)

Figure 2. The triaxial testing set-up: (a) Overview of complete set-up; (b) The UL-60 loading device.

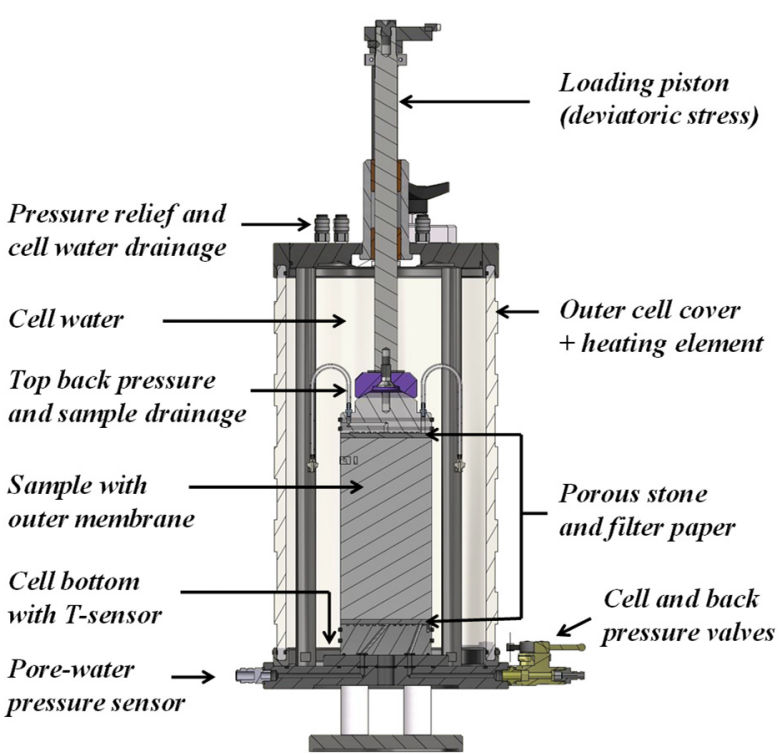

(a)

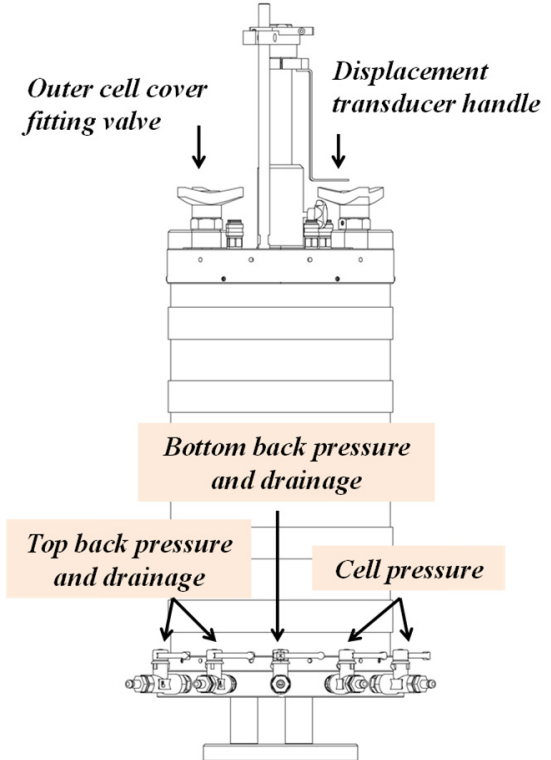

(b)

Figure 3. Schematic depiction of the triaxial cell used in testing the silty clay soil (dimensions of sample size not to scale): (a) Inner section view; (b) Front/Side view.

\subsection{Procedure of Experimental Study}

The specimens of reconstituted silty clay soil for the CD triaxial tests were prepared at their natural field moisture condition. The specimens were prepared with dimensions of $50 \mathrm{~mm}$ diameter and $100 \mathrm{~mm}$ height, in accordance with the specimen preparation standard criteria of ASTM D7181 [15], where a height-to-diameter (H/D) ratio of 2 to 2.5 and a minimum specimen diameter of $33 \mathrm{~mm}$ is suggested. The specimens were prepared by making sure that their upper and lower faces were made flat to provide an even distribution 
of the applied deviatoric loads, and that the bulk density of the silty clay soil was consistent all around the sample volume.

Before the start of each experiment, the water lines below the bottom loading pedestal (i.e., the lower drainage or backpressure line), the upper loading pedestal/cap, the porewater stress sensor located at the rear end of the cell, and the two upper backpressure and drainage lines were thoroughly flushed using de-aired water to eliminate the bound air from the system and all connecting lines. In order to enclose the specimens laterally and to make sure the partition of the back- and cell-pressures, rubber membranes of common standard were used. A porous stone and filter paper combination was placed at each of the bottom and top faces of the specimens, to prevent movement of soil particles through the backpressure and drainage lines. Finally, after putting the samples in the correct position, the rubber membranes were fitted with each of the bottom and top pedestals/caps using very tight O-rings, thus ensuring the separation of the water pressures inside and outside the specimens (i.e., back- or pore-water pressure and the cell-pressure).

Prior to the start of the triaxial testing procedure, and after preparing the specimen and filling the cell with de-aired water, the water in the triaxial cell was heated to the required temperature using the heating pump and circulating heating fluid (glycol mixed with distilled water). For this purpose, adequate temperature stabilization time was provided for the samples. An additional VPC water pressure application and control system was attached to the triaxial cell to avoid an unnecessary increase or build up in the water pressure inside the closed triaxial cell, due to the expansion of the water upon heating. The additional VPC enables the control of the cell water pressure in the triaxial cell by permitting excess water to be removed from the triaxial cell to the pump during the heating process. The pump was then removed once the expansion and temperature of the cell water was in a steady state.

The compression $\mathrm{CD}$ triaxial tests $\left(\sigma_{1}>\sigma_{2}=\sigma_{3}\right)$ were conducted at three cell pressures between 100 and $300 \mathrm{kPa}$, and temperatures of 20,40 and $60^{\circ} \mathrm{C}$, using the pressure stepping or multi-stage compression method [16-18]. With multi-stage compression experiments, the peak strength of the silty clay soil at three cell pressures and isothermal conditions can be determined using only one sample. Afterwards, using these peak stress results, Mohr plots can be drawn, and the shear parameters obtained. Multi-stage compression experiments pose difficulties in the accurate determination of the points of peak stress before moving on to the next step, and hence inherently include errors related to soil state and micro-structural changes in between the various pressure steps [16-18].

However, some of the errors due to major micro-structural changes, which generally occur at high deformations can be prevented or minimized by cautious early termination of the shearing of the sample in the multi-stage compression experiments [17]. Moreover, as reported by Hashimoto et al. [18], the differences between the results of the pressure stepping experiments and the single stage or traditional triaxial tests was minor, and therefore taking into account the various advantages that multi-stage compression experiments have over the conventional triaxial tests (such as saving time, quantity of samples used, and economy), they are suitable and recommended for use.

Overall, the experiments consisted of three phases, namely a saturation phase, consolidation phase and deformation or shearing phase. During the first phase (i.e., saturation), incremental cell or confining pressure steps $\sigma_{3}=\sigma_{\mathrm{c}}$ ranging from 50 to $500 \mathrm{kPa}$ with simultaneous increments of backpressure $\sigma_{\mathrm{b}}$ ranging from 30 to $480 \mathrm{kPa}$ were applied to the specimens, thus having a constant value of effective stress of $20 \mathrm{kPa}$ at all times, under hydrostatic $\left(\sigma_{1}=\sigma_{2}=\sigma_{3}\right)$ and drained conditions. The $B$-value of the samples was regularly calculated during each pressure step of saturation to check the level of saturation and the elimination of remaining or entrapped pore-air from the samples, using an increase of $50 \mathrm{kPa}$ of cell pressure and a minimum target $B$-value of $90 \%$. Once the $\operatorname{target} B$-value was obtained, the consolidation phase of the experiment was started.

During the second phase (i.e., consolidation), the specimens were subjected to consolidation under hydrostatic and drained conditions with a constant value of backpressure 
$\sigma_{\mathrm{b}}$ of $30 \mathrm{kPa}$ and confining or cell pressure values $\sigma_{3}=\sigma_{\mathrm{c}}$ of 100,200 and $300 \mathrm{kPa}$, corresponding to values of effective cell pressures $\sigma_{3}^{\prime}=\sigma^{\prime}{ }_{\mathrm{c}}$ of 70,170 and $270 \mathrm{kPa}$, for the three respective shearing or loading stages, respectively. In this context, each consolidation phase was conducted before the application of vertical deviatoric stress or shearing of the samples corresponding to each loading stage.

Next, for the third phase (i.e., shearing), each specimen was allowed to be deformed or sheared under anisotropic $\left(\sigma_{1}>\sigma_{2}=\sigma_{3}\right)$ and fully drained state at the cell or confining and back- or pore-pressure of each respective consolidation phase. A very slow and constant deformation or shearing rate of $0.014 \mathrm{~mm} / \mathrm{min}$ was used for shearing the samples, in compliance to DIN 18137 [19], to make sure that excessive pore-water stress was not generated during the shearing phase. The deformation phase for each load stage was typically run until peak deviatoric stress condition (without reaching ultimate soil failure).

However, this condition was not able to be attained for some of the samples, where an incessant increase in the deviatoric stress or shear strength without reaching a peak stress condition was experienced. For such instances, the loading phases were stopped without reaching near peak conditions, and after significant levels of strain were attained. This was done so in order to permit for the application of subsequent pressure steps at higher confining stress levels, thus avoiding specimen fattening and the imposition of severe or excessive micro-structural changes in the skeleton of the soil.

Finally, when each shearing phase was completed, the $\sigma_{1}$ deviatoric loading piston was unloaded or retracted back to isotropic condition, before moving on to the start of the next consolidation and loading stage. The data for each test, such as, force or load, displacement or strain, time, temperature, cell pressure, backpressure, pore-water pressure and volume change of the samples were recorded at a sampling interval of $10 \mathrm{~s}$.

The average or mean and differential effective stresses in this manuscript were calculated using the equations: $p^{\prime}=1 / 3\left(\sigma_{1}^{\prime}{ }_{1}+\sigma_{2}^{\prime}+\sigma_{3}^{\prime}\right)=1 / 3\left(\sigma_{1}^{\prime}+2 \sigma_{3}^{\prime}\right)$ and $q=\sigma_{1}^{\prime}-\sigma_{3}^{\prime}$, respectively. The symbols $\sigma_{1}^{\prime}{ }_{1}, \sigma_{2}^{\prime}$ and $\sigma_{3}^{\prime}$ represent the principal effective compressive stress states, and were calculated by deducting the quantity of the pore-water pressure $u$ in the samples from the total value of principal compressive stresses $\sigma$. From the slope $M$ of the $p^{\prime}-q$ stress diagram, the peak effective angle of internal friction $\phi^{\prime}$ of the samples at failure was calculated using the equation: $\phi^{\prime}=\sin ^{-1}\left(\frac{3 M}{6+M}\right)$.

\section{Obtained Results and Discussion}

\subsection{Saturation Phase Results}

In Figure 4, the progress of the saturation phases of the silty clay soil measured at room temperature is shown. The saturation process typically took around $120 \mathrm{~h}$ for completion, and in this time the cell or confining stress $\sigma_{3}=\sigma_{\mathrm{c}}$ of the sample was gradually increased from 50 to $500 \mathrm{kPa}$, thus keeping an effective stress of around $20 \mathrm{kPa}$ in the sample throughout the duration of the saturation phase of the CD test.

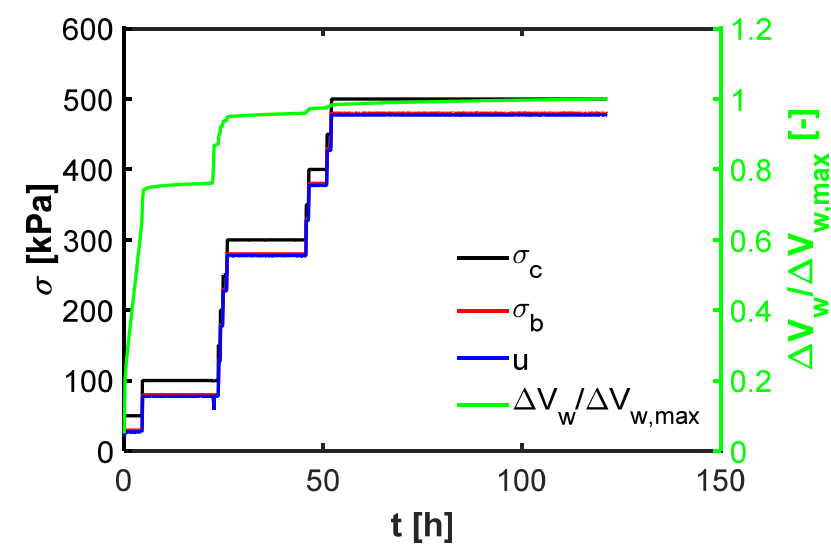

Figure 4. Saturation phase time plot of the silty clay soil at room temperature. 
During the early phases (application of confining pressures of 50 and $100 \mathrm{kPa}$ ), the backpressure was only applied from the bottom side of the sample by also opening the top drainage valve from time to time. This enabled the pore-air entrapped in the sample to be freed and pushed out from the top face of the sample (i.e., free drainage). Once it was confirmed that the volume of water entering-to and leaving-from the specimen were almost the same, showing the elimination of most of the free or unbound pore-air in the sample, the drainage line from the top face of the sample was closed. Afterwards, this top drainage line was then connected to the backpressure application line, thus enabling the application of the backpressure and the buildup of pore-water pressure in the specimen from both its top and bottom sides.

Then, the confining or cell and back-pressures were incrementally and simultaneously increased to their maximum set values. This allowed for the remaining few quantities of bound gas or air pressures which were still left in the soil pores to be dissolved in the pore-water solution at a high-pressure state. Once the confining or cell pressure value of $500 \mathrm{kPa}$ was reached, the changes in the amount of volume of water $\Delta V_{w}$ recorded entering the silty clay soil sample at high pressure was quite low, and therefore, an extra increment of the confining or cell pressure was deemed not necessary. This whole process facilitated the achievement of the set-out target $B$-value of the sample, demonstrating the near complete saturation of the silty clay soil samples.

\subsection{Consolidation Phase Results}

Figure 5 shows the results of the first stage consolidation (effective cell or confining stress $\sigma_{3}^{\prime}=\sigma^{\prime}{ }_{\mathrm{c}}=70 \mathrm{kPa}$ ) of the $\mathrm{CD}$ triaxial test of the silty clay soil at room temperature. This first stage of consolidation was performed by reducing the confining stress of the soil from 500 to $100 \mathrm{kPa}$, and by simultaneously slowly reducing the backpressure applied to the sample from 480 to $30 \mathrm{kPa}$, hence escalating the effective confining stress of the silty clay soil from $20 \mathrm{kPa}$ to $70 \mathrm{kPa}$. This increase in the applied effective confining stress enabled the removal of excess pore-water from the fully saturated sample, as can be seen by (and is equivalent to) the negative quantity of volume change $\Delta V$ of the silty clay specimen in Figure 5 .

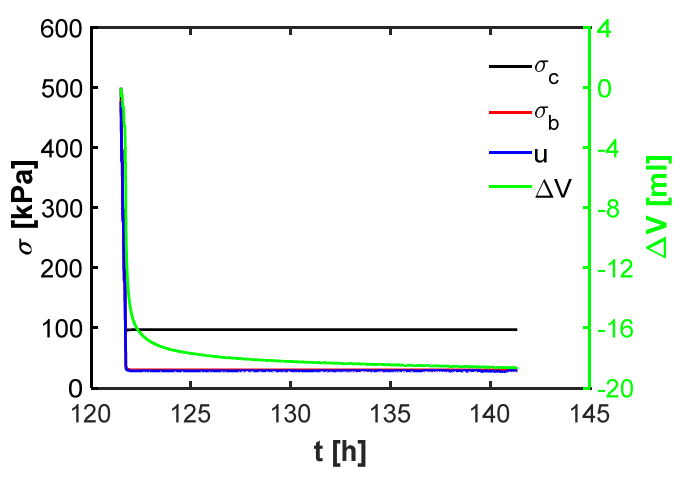

(a)

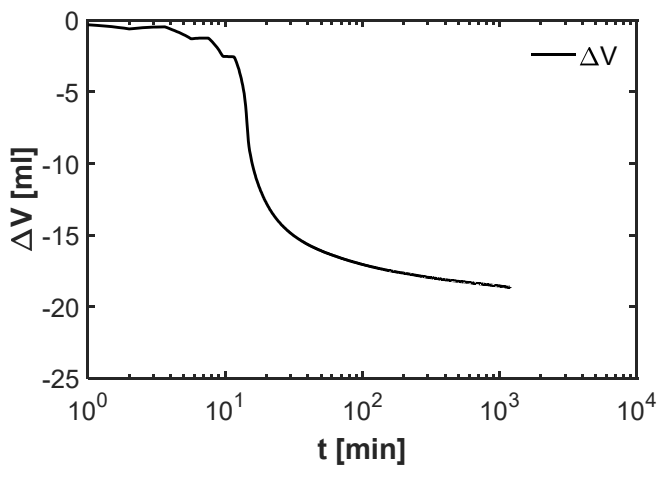

(b)

Figure 5. Results of the consolidation phase of the CD triaxial test of the silty clay soil at room temperature: (a) Pressures/volume change of the soil vs. time; (b) Volume change of the soil vs. time.

\subsection{Shearing or Deformation Phase Results}

In Figure 6, plots of the stress-strain diagrams (i.e., axial compressive strain $\varepsilon_{a}$ vs. deviatoric or differential stress $q$ ), triaxial stress state diagrams (i.e., $p^{\prime}-q$ ), and axial-tovolumetric strain diagrams (i.e., axial compressive strain $\varepsilon_{a}$ vs. volumetric strain $\varepsilon_{v}$ ) of the shearing or deformation phases of the $\mathrm{CD}$ triaxial compression tests on the silty clay soil at the temperature $T$ range of 20 to $60{ }^{\circ} \mathrm{C}$ are presented. From the stress-strain plots it can be seen that, overall, the silty clay soil demonstrated a strain-hardening behavior at all strain 
ranges before reaching near-peak stress state. This strain-hardening behavior was evident in the soil at all the studied temperatures (Figure $6 \mathrm{a}-\mathrm{c}$ ).

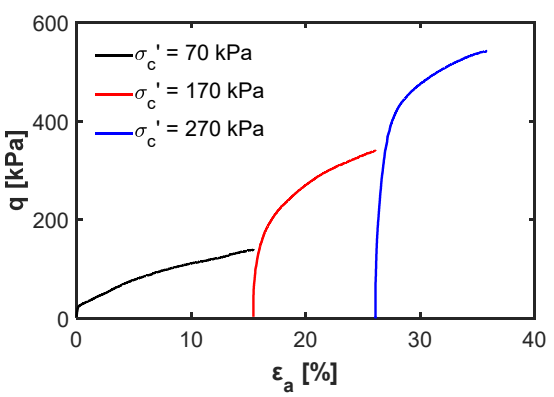

(a)

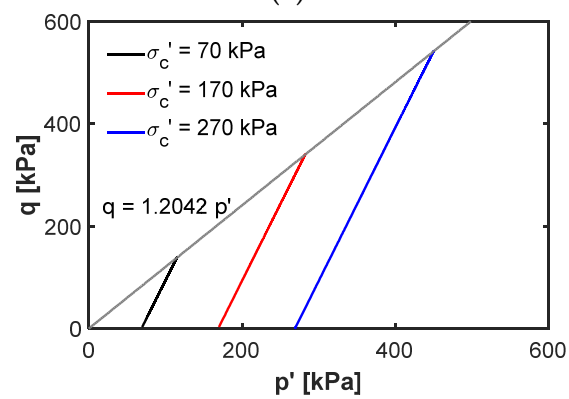

(d)

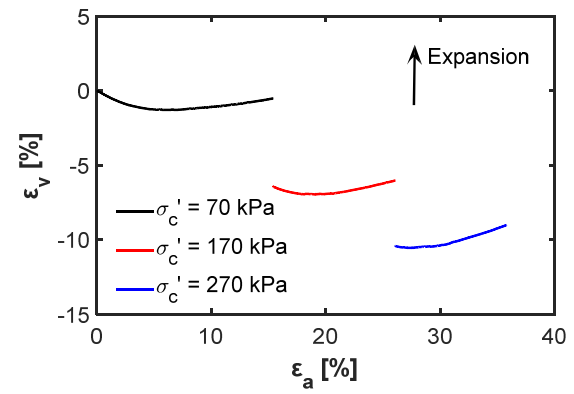

(g)

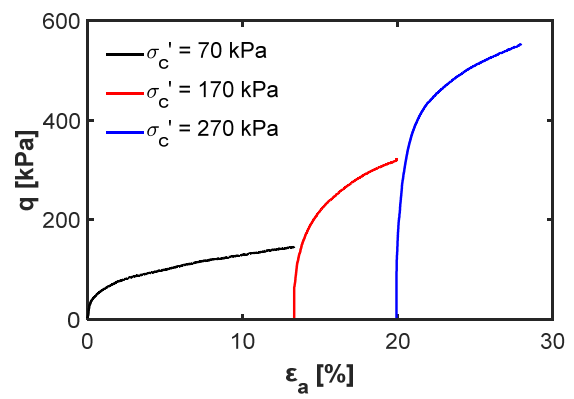

(b)

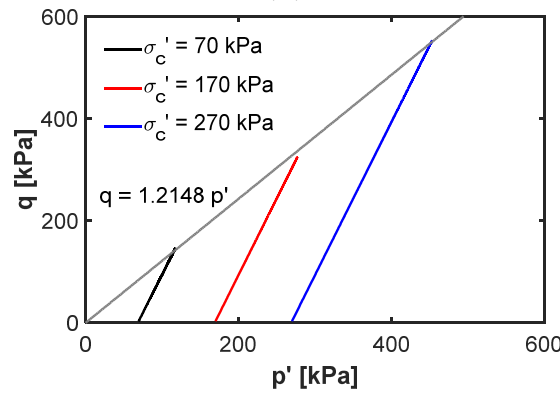

(e)

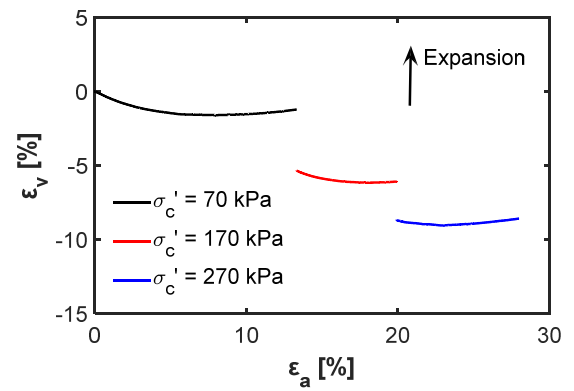

(h)

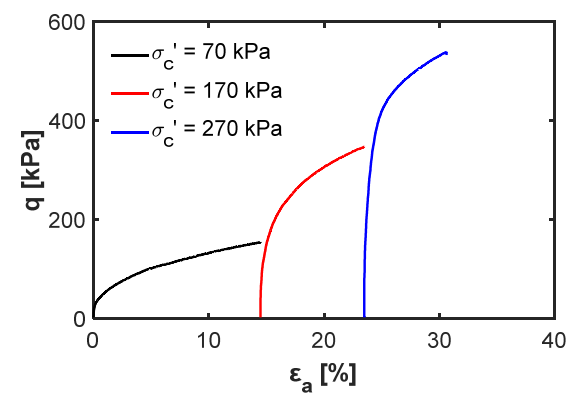

(c)

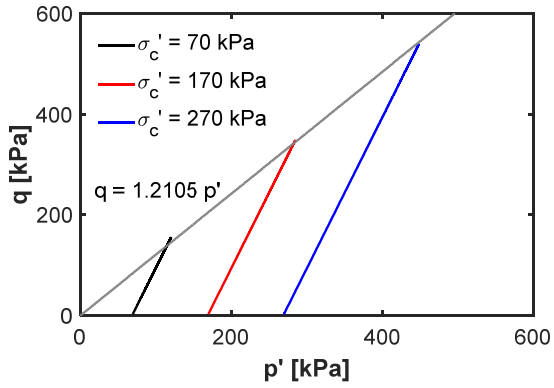

(f)

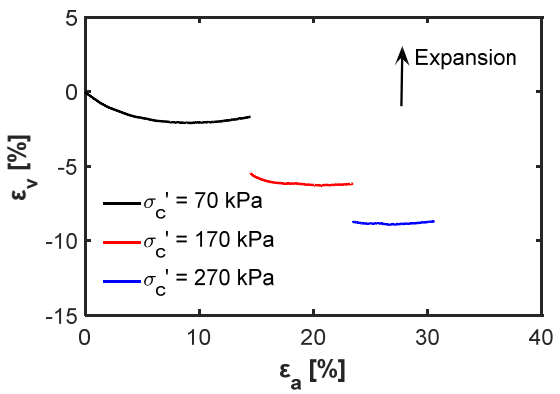

(i)

Figure 6. Shearing or deformation phase results of the silty clay soil at: $(\mathbf{a}, \mathbf{d}, \mathbf{g}) \mathrm{T}=20^{\circ} \mathrm{C}$; (b,e,h) $\mathrm{T}=40{ }^{\circ} \mathrm{C} ;(\mathbf{c}, \mathbf{f}, \mathbf{i}) \mathrm{T}=60^{\circ} \mathrm{C}$.

Considering the $\varepsilon_{a}$ vs. $q$ plots of the silty clay soil at the different temperatures considered in this study, and more specifically during the first stage of shearing $\left(\sigma^{\prime}{ }_{3}=\sigma^{\prime}{ }_{\mathrm{C}}=70 \mathrm{kPa}\right)$, where the silty clay soil samples are in large micro-structurally unchanged, the soil showed a relatively higher bulk axial compressive strain $\varepsilon_{a}$ (more than $10 \%$ at all temperature conditions) at near peak deviatoric stress $q$ states. This demonstrates a very low stiffness modulus or a very high ductility of the grain skeletons of the silty clay soil, which are predominantly comprised quartz and calcite mineral forms. This is also corroborated by the very high degree of fattening or bulging rather than diagonal cracking failure of the samples as shown by the images of the specimens taken after the completion of the multi-stage shearing tests (Figure 7). From the images, when comparing the results from the different temperature states studied in this research, no clear difference in the failure pattern of the soil during shearing can be observed (Figure 7). 


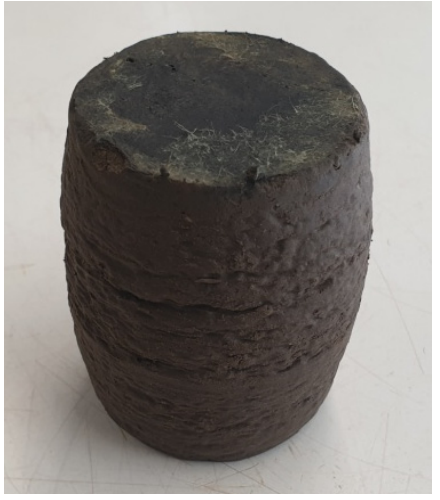

(a)

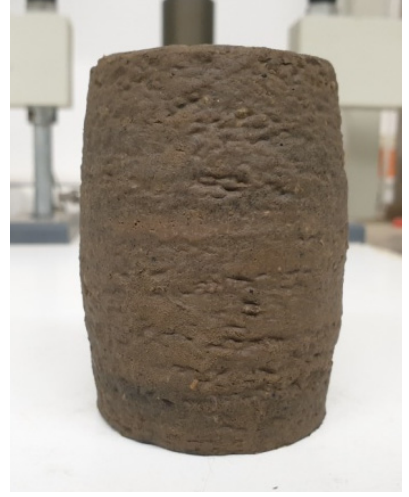

(b)

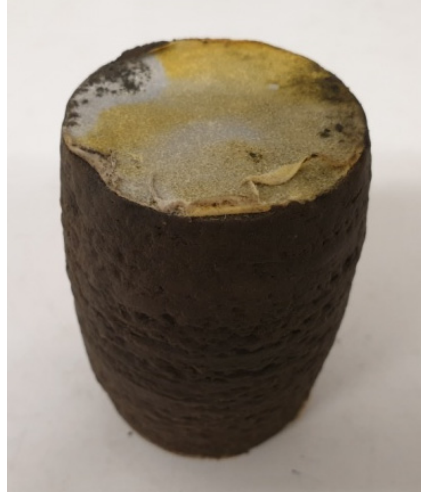

(c)

Figure 7. Sheared (after test) specimen images of the $\mathrm{CD}$ tests on the silty clay soil at: (a) $\mathrm{T}=20^{\circ} \mathrm{C}$; (b) $\mathrm{T}=40^{\circ} \mathrm{C}$; (c) $\mathrm{T}=60^{\circ} \mathrm{C}$.

At room temperature, the normally consolidated soil having a moderate density, exhibited minor contractions at the beginning of the test (low shear strain levels), which was then followed by an expansion or dilation by an almost equal magnitude at higher strain levels, for all shearing or deformation stages (Figure $6 \mathrm{~g}$ ). The minor initial contraction of the soil exhibited at the beginning of the test which was followed by a dilation of an almost equal magnitude is what one would expect for a normally consolidated soil with moderate density. This is also corroborated by the findings of previous studies, which showed that dense overconsolidated soils tend to dilate strongly upon shearing while loose normally consolidated soils tend to compress strongly when sheared [20,21].

At elevated temperatures however, the soil showed only an initial compaction or contraction without any significant or noticeable dilatant behavior at higher levels of shear strain (Figure 6h,i). In saturated soils, the volume and pore-pressure changes that are induced due to temperature changes are related to interactions of the thermal expansion of soil minerals and water, their compressibility, and changes in interparticle forces [11]. Plum and Esrig [22] postulated that heating of saturated fine-grained soils produces a volume decrease (compactive behavior) of the soil due to the expansion of the double layers, thus increasing the soil repulsive forces. However, contradictory statements can be found in the literature regarding the effects of heating on the double layer thickness and interparticle repulsive forces [11]. The results of our study, which showed that at elevated temperatures, the silty clay soil lost its ability to dilate during shearing as compared to that of room temperature, indicates the possibility of a reduction of the double layer thickness of the clay fraction of the soil during heating, thus causing a volume increase (loosening) of the soil prior to the start of the shearing phase. When sheared, this soil in a comparatively looser state will then primarily compact in line with the typical behavior of loose normally consolidated soils upon shearing.

Moreover, for the $\varepsilon_{a}$ vs. $\varepsilon_{v}$ plots, the compactions of the sample due to the applied effective consolidation loads during the various consolidation phases of the different loading stages of the multi-stage compression experiments are shown by the vertical drops of the recorded volumetric strain data $\varepsilon_{v}$ located between the three shearing or deformation phases of the soil (Figure $6 \mathrm{~g}-\mathrm{i}$ ).

Broadly speaking, the measured peak effective angle of internal friction $\phi^{\prime}$ of the silty clay soil at room temperature condition (around $30^{\circ}$, or slope at peak failure state $M$ of the $p^{\prime}-q$ diagram of around 1.20) is similar to those of the typically recorded values for normally consolidated silty-clayey (CL, ML) soils (ranging between 28 and $32^{\circ}$ ) from the literature [20,23].

Assessing the effect of temperature on the effective shear strength behavior or peak deviatoric stress condition at failure (Figure 8, Table 2), the silty clay soil exhibited very minor changes (or a slight increase) in its measured peak effective angle of internal friction $\phi^{\prime}$ and slope at peak failure state $M$ of the $p^{\prime}-q$ diagram with an increase in medium 
temperature from 20 to $60^{\circ} \mathrm{C}$. Hence, for practical purposes, the effective shear strength behavior of the silty clay soil can be assumed to be independent of temperature for the range considered in this study.

Previous studies $[1,8,21]$ indicated that when heated to high temperature states, overconsolidated soils with high density generally exhibit a thermal expansive or dilatant behavior, thus losing shear strength, whereas normally consolidated or loose soils with a relatively low density exhibit a thermal compaction or contractive behavior when heated, thus gaining shear strength, due to the creation of a more compact soil volume after grain restructuring in the soil skeleton due to the heating process. Considering the above factors and the moderate initial density of the silty clay soil used in this research, the results (i.e., negligible changes in shear strength of soil after heating) presented in this study corroborate these previous findings.

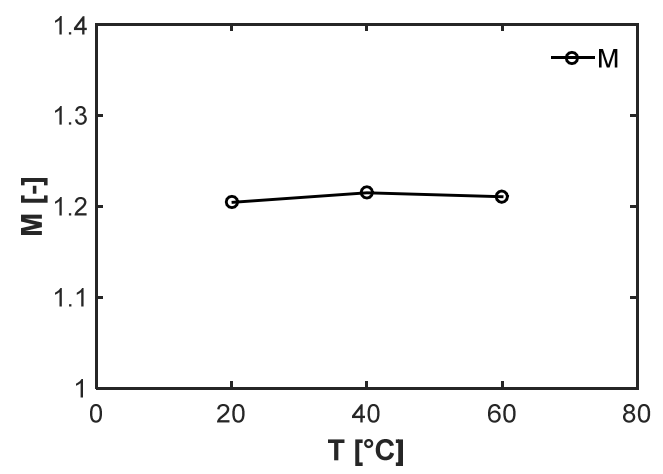

(a)

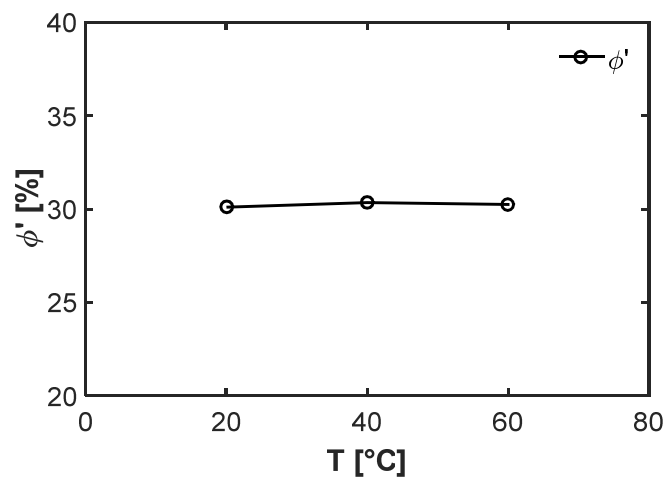

(b)

Figure 8. Variations of: (a) $M$; (b) $\phi^{\prime}$, of the silty clay soil with temperature $T$.

Table 2. Variations of $M$ and $\phi^{\prime}$ of the silty clay soil with temperature.

\begin{tabular}{ccc}
\hline Temperature $\left({ }^{\circ} \mathbf{C}\right)$ & $M(-)$ & $\boldsymbol{\phi}^{\prime}\left({ }^{\circ}\right)$ \\
\hline 20 & 1.2042 & 30.10 \\
40 & 1.2148 & 30.34 \\
60 & 1.2105 & 30.24 \\
\hline
\end{tabular}

\section{Conclusions}

The results of an experimental study on the effects of temperature on the shear strength behavior of a silty clay soil from eastern Germany were presented. The consolidated drained (CD) compression triaxial tests were conducted on remolded specimens at the temperatures of 20,40 and $60^{\circ} \mathrm{C}$ with a triaxial device which can regulate the temperature of the soil. The findings of the study showed that the measured peak effective angle of internal friction of the silty clay soil recorded at room temperature (around $30^{\circ}$ ) is similar to those of the typically recorded values for normally consolidated silty-clayey soils reported in the literature. Moreover, the results indicated very minor or negligible changes in the measured peak effective angle of internal friction values of the soil with changes in temperature for the range considered in this study.

Considering the moderate initial density state of the silty clay soil used in this research, the results (i.e., negligible changes in shear strength of soil after heating) presented in this study corroborate previous findings from the literature which indicated that overconsolidated soils with high density generally exhibit a thermal expansive or dilatant behavior when heated, thus losing strength in their shear capacity, while normally consolidated or loose soils with a relatively low density exhibit a thermal compaction or contractive behavior when heated, thus gaining strength in their shear capacity.

However, the volume change behavior of the soil was found to exhibit some variations with changes in temperature, i.e., at elevated temperatures the silty clay soil lost its ability to 
dilate during shearing as compared to that of room temperature, possibly due to a reduction of the double layer thickness of the clay fraction of the soil upon heating, thus causing a volume increase (loosening) of the soil prior to shearing. Considering the contradictory reports found in the literature regarding the effect of heating on the double layer thickness of clay minerals and soil repulsive forces, more research is needed to obtain a clear link between the two.

Author Contributions: Conceptualization, H.H.; methodology, H.H.; software, H.H.; validation, H.H.; formal analysis, H.H.; investigation, H.H.; resources, H.H. and F.W.; data curation, H.H.; writing - original draft preparation, H.H.; writing_review and editing, H.H. and F.W.; visualization, H.H.; project administration, F.W.; funding acquisition, F.W. All authors have read and agreed to the published version of the manuscript.

Funding: This study was financially supported by the German Federal Ministry for Economic Affairs and Energy (BMWi) under Project ANGUS II (Grant number: 03ET6122A).

Data Availability Statement: No public data repository.

Acknowledgments: The authors would like to acknowledge the support of Project Management Jülich. We thank APS Antriebs-, Prüf- und Steuertechnik GmbH, Rosdorf, Germany, for kindly granting us use of the raw images for the schematic representations of the triaxial device shown in Figures $2 \mathrm{~b}$ and 3 . We would also like to thank Brendan Ledwig of Kiel University for his help in analyzing the XRD measurements of the silty clay soil.

Conflicts of Interest: The authors declare no conflict of interest.

\section{References}

1. Burghignoli, A.; Desideri, A.; Miliziano, S. A laboratory study on the thermomechanical behaviour of clayey soils. Can. Geotech. J. 2000, 37, 764-780. [CrossRef]

2. Gray, H. Progress report on research on the consolidation of fine-grained soils. In Proceedings of the First International Conference on Soil Mechanics and Foundation Engineering, Cambridge, MA, USA, 22-26 June 1936; Volume 2, pp. $138-141$.

3. Campanella, R.G.; Mitchell, J.R. Influence of temperature variations on soil behavior. J. Soil Mech. Found. Div. Asce 1968, 94, 709-734. [CrossRef]

4. Cui, Y.J.; Sultan, N.; Delage, P. A thermomechanical model for saturated clays. Can. Geotech. J. 2000, 37, 607-620. [CrossRef]

5. Abuel-Naga, H.M.; Bergado, D.T.; Lim, B.F. Effect of temperature on shear strength and yielding behavior of soft Bangkok clay. Soils Found. 2007, 47, 423-436. [CrossRef]

6. Hueckel, T.; François, B.; Laloui, L. Explaining thermal failure in saturated clays. Géotechnique 2009, 59, 197-212. [CrossRef]

7. Uchaipichat, A.; Khalili, N. Experimental investigation of thermo-hydro-mechanical behaviour of an unsaturated silt. Géotechnique 2009, 59, 339-353. [CrossRef]

8. Vega, A.; McCartney, J.S. Cyclic heating effects on thermal volume change of silt. Environ. Geotech. 2015, 2, 257-268. [CrossRef]

9. Moritz, L. Geotechnical Properties of Clay at Elevated Temperatures; Report No. 47; Swedish Geotechnical Institute: Linköping, Sweden, 1995.

10. Abuel-Naga, H.M.; Bergado, D.T.; Soralump, S.; Rujivipat, P. Thermal consolidation of soft Bangkok Clay. Lowl. Technol. Int. 2005, 7, 13-21.

11. Mitchell, J.K. Temperature Effects on the Engineering Properties and Behavior of Soils; Effects of Temperature and Heat on Engineering Behavior of Soils, Special Report 103; Highway Res. Board (HRB): Washington, DC, USA, 1969; pp. 9-28.

12. Laloui, L. Thermo-mechanical behaviour of soils. Rev. Française Génie Civ. 2001, 5, 809-843. [CrossRef]

13. Scaringi, G.; Loche, M. A thermo-hydro-mechanical approach to soil slope stability under climate change. Geomorphology 2022, 401, 108108. [CrossRef]

14. ASTM D420-D5876; Soil and Rock (I). ASTM International: West Conshohocken, PA, USA, 2011.

15. ASTM D7181; Standard Test Method for Consolidated Drained Triaxial Compression Test for Soils. ASTM International: West Conshohocken, PA, USA, 2020.

16. Head, K.H. Effective Stress Tests. Manual of Soil Laboratory Testing, 2nd ed.; Wiley: West Sussex, UK, 1998; Volume 3.

17. Stipp, M.; Rolfs, M.; Kitamura, Y.; Behrmann, J.H.; Schumann, K.; Schulte-Kortnack, D.; Feeser, V. Strong sediments at the deformation front, and weak sediments at the rear of the Nankai accretionary prism, revealed by triaxial deformation experiments. Geochem. Geophys. Geosystems 2013, 14, 4791-4810. [CrossRef]

18. Hashimoto, Y.; Stipp, M.; Lewis, J.C.; Wuttke, F. Paleo-stress orientations and magnitudes from triaxial testing and stress inversion analysis in Nankai accretionary prism sediments. Prog. Earth Planet. Sci. 2019, 6, 3. [CrossRef]

19. DIN 18137. Soil, Testing Procedures and Testing Equipment; Determination of Shear Strength: Triaxial Test, Part 2; Deutsches Institut für Normung e.V. (DIN): Berlin, Germany, 2020. (In German) 
20. SCDOT. Geotechnical Design Manual, Chapter 7: Geomechanics, 2nd ed.; South Carolina Department of Transportation (SCDOT): Columbia, SC, USA, 2019.

21. Hailemariam, H.; Wuttke, F. A laboratory study on the shear strength behavior of two till deposits from Northern Germany. Energies 2021, 14, 1692. [CrossRef]

22. Plum, R.L.; Esrig, M.I. Some Temperature Effects on Soil Compressibility and Pore Water Pressure; Special Report 103; Highway Res. Board (HRB): Washington, DC, USA, 1969; pp. 231-242.

23. Carter, M.; Bentley, S.P. Soil Properties and Their Correlations, 2nd ed.; Wiley: West Sussex, UK, 2016. 